\title{
Frère Emmanuel de Taizé, Un amour méconnu. Au-delà des représentations spontanées de Dieu, Paris Bayard 2008, 256 s.
}

Książka brata Emmanuela z Taizé, wydana staraniem wydawnictwa Bayard, powstała w języku francuskim w roku 2008. Doczekała się ona wielu przekładów na języki obce. Duże zainteresowanie wzbudziło tłumaczenie angielskie, które liczy już kilka wydań. Niewątpliwie wynika to zarówno z ogromnej wartości książki i poruszanych w niej problemów, jak i z osobistego zaangażowania autora, który często uczestniczy w prelekcjach na temat spontanicznych obrazów Boga, organizowanych na uniwersytetach, w parafiach, w centrach formacji chrześcijańskiej w USA. Brat Emmanuel ,,jako młody człowiek - jak pisze w przedmowie do książki brat François z Taizé - poszukując ideału, podjął wspólnotowe życie monastyczne, gdzie często słyszał, jak brat Roger mówił do braci lub do tych, którzy byli przejazdem w Taizé, że: «Bóg może jedynie kochać». Powtarzanie tych słów ukazywało stały wysiłek w przekonywaniu ludzi poszukujących Boga, że w Nim mogą posiąść prawdziwą miłość. Sam brat Roger, od młodych lat, był mocno uwrażliwiony na zwroty językowe, którymi opisywano Boga, a które, choć używane w dobrych intencjach, utrudniały okazywanie Bogu należnego zaufania, czasem nawet raniły i budziły wątpliwości”. W książce Un amour méconnu nie chodzi o miłość nieznaną, taką, o której się nie mówi. Bo przecież, jak zauważa autor, czyż jest ktoś, kto by nawet pośrednio nie słyszał o Bogu, który jest miłością, o Bożej miłości? Na ponad 250 stronach brat Emmanuel wprawnym piórem opisuje zagadnienia miłości źle poznanej, wręcz niedocenionej. Ukazuje on wszelkiego rodzaju mechanizmy, które kreują w nas spontaniczny, często zafałszowany obraz Boga, tworzą Jego karykaturę.

Zarówno życie w świecie, w którym - wydawałoby się - zło święci swój triumf, jak i pojawiający się przy tym często problem cierpienia nie sprzyjają poszukiwaniu odpowiedzi na pytanie o istnienie Boga 
Sprawozdania i recenzje miłości. Wielokrotnie napotykane trudności tej natury stają się podstawą dzisiejszego ateizmu. Bunt i zwątpienie mogą pojawić się też wśród ludzi wierzących, którzy obecność zła i cierpienia próbują wytłumaczyć oskarżaniem Boga o cichą zmowę ze złem. Pytanie o sens życia czy też każde inne doświadczenie duchowe muszą się z takimi wątpliwościami zmierzyć. Na drodze świadomego rozwoju duchowego, jak podkreśla brat Emmanuel, takie doświadczenie stanowi pierwszy, a przynajmniej obowiązkowy etap. Takiemu właśnie doświadczeniu poświęcona jest pierwsza część książki. Czytelnik może z łatwością odnaleźć w niej różne przykłady zła, za którego istnienie obwinia się Boga Stwórcę. Jest tam także zawarte konkretne wsparcie duchowe, jakiego mogą udzielić człowiekowi nauki ścisłe wyznaczające punkty styczne pomiędzy nauką a wiarą. Czytelnik - bez względu na to, czy jest osobą wierzącą, czy nie - zachęcany jest do nabrania dystansu i zmiany postrzegania pozornego rozdźwięku pomiędzy Bogiem miłości a światem.

W drugiej części książki brat Emmanuel odkrywa istniejące w człowieku mechanizmy, które sprawiają, że przy konfrontacji ze złem budzą się w nim ukryte lęki, które wypaczają obraz Boga. Obawy uświadomione lub nie, rozpoznane lub ukryte, natarczywe czy też stłumione biorą się najczęściej z trudności uwierzenia w to, że każdy jest godny tego, by być kochanym. Podejmowana próba lepszego poznania swojego wnętrza, etapów swojego rozwoju psychologicznego, umożliwia życzliwe spojrzenie na siebie, a w konsekwencji pozwala na dystans wobec surowego osądu przypisywanego Bogu. Autor wskazuje także na różnego rodzaju zranienia oraz sposób postrzegania tych zranień przez miłującego Boga. Konfrontacja z samym sobą pozwala na zupełne otwarcie się na nową perspektywę.

Podjęcie intensywnego życia wewnętrznego wspomaga przełamanie ukrytych lęków przed Bogiem. Taka intensyfikacja doświadczenia duchowego napotyka jednak wiele przeszkód, m.in. taką, że pojęcie Bożej transcendencji wywołuje u niektórych poczucie istnienia Boga wywyższającego się czy zwyczajnie odległego. Doświadczenie takie, jak wskazuje brat Emmanuel, jednych prowadzi do braku zainteresowania doświadczeniem duchowym, a drugich do budowania relacji pan - niewolnik. Refleksja nad psychicznym podłożem takich zachowań pomaga dostrzec prawdziwą transcendencję i wielkość Boga.

Obraz Boga odległego czy narzucającego się nie jest obrazem Boga z Ksiąg Objawienia, który jest spragniony bliskości z człowiekiem, który nie tylko kocha swoje stworzenie, lecz także chce być przez nie kochany. Nasze postrzeganie Boga zmienia się wraz z uświadomieniem 
sobie faktu, że Bóg pragnie kochać człowieka. Autor w kolejnych częściach swej książki pisze o takim właśnie Bogu i ukazuje stopniowo drogi do zbudowania większego zaufania. Stwarza to także wiele okazji do podjęcia refleksji związanych z odwoływaniem się do analogii w życiu człowieka: zarówno analogii negatywnych, które psują obraz Boga, jak i pozytywnych, które ten obraz odfałszowują.

Mocną stroną omawianej publikacji jest jej uniwersalizm. Brat Emmanuel kieruje wiele słów nie tylko do wierzących, lecz także do niewierzących. Często zaprasza ich do tego, aby nie budowali swojej religijności na podstawie zubożałych wyobrażeń czy wręcz karykatur Boga najczęściej utrwalonych w dzieciństwie i młodości.

Lektura książki Un amour méconnu brata Emmanuela może być cenną motywacją do tego, aby nieustannie poznawać siebie, podejmować integrację swojego człowieczeństwa, wrażliwości, tożsamości płciowej, sposobu bycia i kochania - niezależnie od przekonań religijnych czy też nawet wobec zadeklarowanego braku wiary. Kto wie, czy nie może stać się ona nawet miejscem odnalezienia lub odzyskania wiary . Dla idących zaś drogą mistyki chrześcijańskiej książka ta jest dobrym przewodnikiem. Nazwanie częściowo podświadomych procesów pozwala uwolnić się od najbardziej rozpowszechnionych spontanicznych wyobrażeń Boga. Jest zachętą do ponownego lub nowego odkrycia niedocenianej miłości Boga, który nie chce zła i nie zgadza się na nie, który zaprasza do wejścia z Nim od zaraz w głęboką relację miłości. Wnikliwe rozważania brata Emmanuela na temat poznawania istniejących w nas mechanizmów fałszujących obraz Boga są próbą ukazania przenikania się codzienności z życiem wewnętrznym.

Doświadczenie Bożej miłości jest czymś bardzo indywidualnym. Stąd też historia tej książki „nie jest zatem - jak pisze brat François - zakończona. Poszukiwania trwają. Mówienie o Bogu w odpowiedni sposób zawsze pozostanie poza naszym zasięgiem. A jeśli, mówiąc o Nim, chcemy być zrozumiali, powinniśmy się wsłuchiwać w najważniejsze pytania naszych czasów". 